\title{
Design of English Learning Application for Children Early Childhood
}

\author{
Very Hendra Saputra ${ }^{1 *}$, Donaya Pasha ${ }^{2}$, Yolanda Afriska ${ }^{3}$ \\ ${ }^{1}$ Mathematich Education Department, Faculty of Education and Teacher Training, Universitas Teknokrat Indonesia \\ ${ }^{2.3}$ Information System Departement, Faculty of Engineering and Computer Science, Universitas Teknokrat Indonesia \\ J1. ZA. Pagar Alam No.9-11, Labuhan Ratu, Kec. Kedaton, Kota Bandar Lampung, Lampung 35132 \\ Email*: very_hendra@teknokrat.ac.id
}

\begin{abstract}
Early childhood development includes several aspects such as physical, motor, language, social and cognitive. Cognitive factors are important role because most learning activities are always related to thinking and remembering problems. Besides language development is very important, it is because language is a communication tool of children with their environment, with good communication it will result in good interactions. Therefore, children need to be given the right stimulus so that during the child's growth and development to the maximum. One stimulus that can be given for cognitive development and language of early childhood is by providing an interesting medium, because in the development of early childhood the way of thinking requires visualization of abstract thinking. The purpose of this research is to design an application of learning English for mobile-based early childhood which is expected to be used as an lalternative as a medium to assist cognitive development and communication of early childhood. English based learning applications for mobile children are made with Construct 2 software. The development method uses the Multimedia Development Life Cycle. While testing the application using ISO 9126, the results of testing the quality of the application using ISO 9126 which includes the Functionality and Usability characteristics obtained Functionality test results obtained value of $100 \%$, and the Usability test results obtained value of $91.11 \%$ so it can be concluded that the design of English learning applications is appropriate to be used as a medium to assist cognitive development and communication of early childhood.
\end{abstract}

Keywords : Early Childhood, Construct2, ISO 9126

\section{INTRODUCTION}

Early childhood development is the golden stage. So that the right stimulus is needed, so that early child hood development is more maximal. Early child hood development includes several aspects, namely cognitive, motor, physical, social and language development. Therefore, to support child development, supporting facilities are needed in the hope that it can facilitate early child hood exploration of their development which impacts on their cognitive abilities.

The development of language aspects is important because with good language, communication will go well. With good communication, children can explore knowledge maximally. One of the tools that can be used is by giving media as a tool in exploring early childhood knowledge, because the function of learning media is as a message delivery, with messages conveyed clearly will result in the amount of knowledge gained. Media that are designed based on student characteristics, can improve student communication and become learning media that can motivate students in the learning process (Very H.S, 2017).

Characteristics of early childhood learning that is visualizing something that is abstract, we need tools that can help revise it. Results of research conducted by (Miftakh., F , 2015) states the ability to listen to students who learn with the help of audio-visual media is better and students are more motivated when learning takes place. While (Grossard. C, O. at al, 2017) the results of the study stated student understand easily the concept of selecti on sort by looking at the visualization. Learning material text is more affective if it is p rovided with graphic, animation, or video to be learned by student.

Research related to the function of instructional media in the educational process has given many contributions to the learning process, especially overcoming the problem of understanding students' concepts of subject matter. (Very. H.S, 2018), in his research stated that learning media can visualize abstract subject matter and facilitate mastery of student concepts. In other research related to instructional media, (Very, H.S, 2019) gets the results that the learning process using animation media can improve student creativity and student communication.

Early child hood learning in addition to visualizing something abstract, they also learn by imagining, early child hood love to imagine and develop things that are far from the real conditions. Therefore in this study a learning media will be designed that can help students visualize something abstract in the hope that they can help early childhood in exploring knowledge

\section{MATERIALS AND METHODS}

\section{Development Method}

The development method used in this research is the development method of Multimedia Development Life Cycle (MDLC) which includes concept, design, material 
collecting, assembly, testing and distribution. (Sutopo, A. H., 2003)

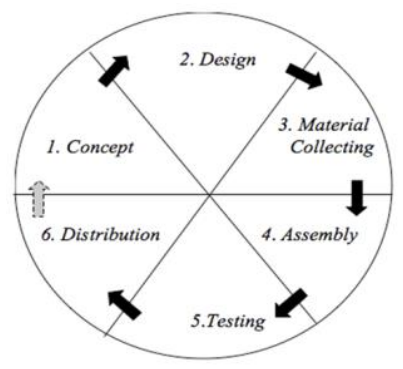

Figure 1. MDLC Multimedia Development Methodology.

\section{Concept.}

The concept stage aims to determine who is the user of the program, with what software the media will be made and determine the content of the media to be developed (entertainment, training, learning, etc.).

\section{Design.}

At this stage the specifications of the program architecture, style, appearance and material requirements for the program will be determined. This media design uses storyboarding, flowchart.

\section{Collcting Materials.}

Collecting materials such as images, animations, audio, photos, etc. that are used to fill learning media.

\section{Assembly.}

All collected objects or materials are created using software construct 2. Making an application is based on the design stage.

\section{Testing.}

Testing is done after completion of the manufacturing phase and all data has been entered, by running the application / program and see whether there are errors or not. Product testing to see the feasibility of media products that have been made is the ISO 9162 test.

\section{Distribution}

Stages where the application is stored in a storage media. Distribution (Distribution) distribution stage is the stage where the application is stored in a storage medium.

\section{ISO 9126}

Assessment standard for English language learning media software for early childhood is one of the software, because the results of this learning media can be operated on an android-based mobile phone.

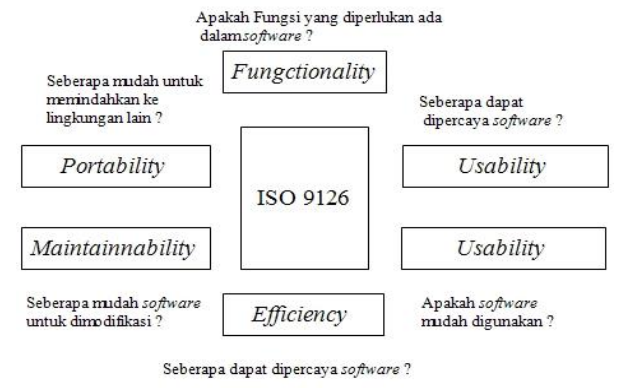

Figure 2. ISO 9126 Quality Characteristics (ISO/IEC 9126-1, 2001).

\section{Design System}

The objectives and literature of this multimedia stage are designed with a Work Breakdown Structure (WBS) so that it can be explained in detail and in stages.

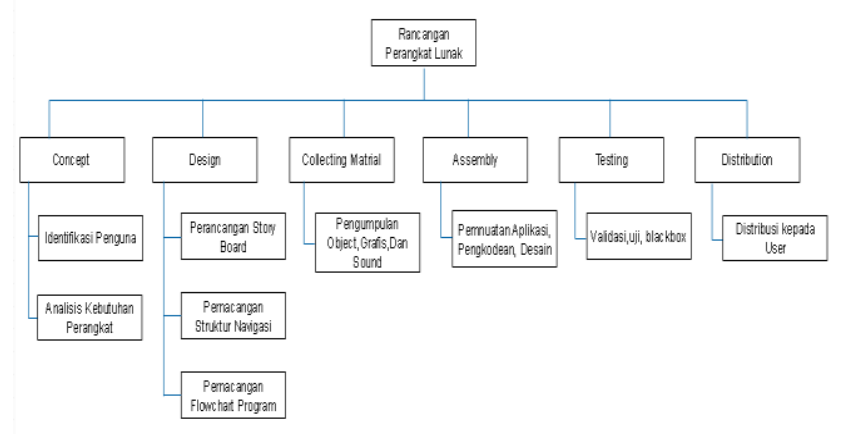

Figure 3. Work Breakdown Structure.

\section{Concept}

At this stage the objectives of the application, as well as the user, are determined. The purpose of this application is to design learning applications in the form of English learning media for early childhood. Here is a description of the concept of learning media for early childhood

Table 1. Description. Application Concept

\begin{tabular}{|ll|}
\hline Title & $: \begin{array}{l}\text { English Based Learning Application For Early } \\
\text { Childhood Mobile Based }\end{array}$ \\
Type & $: \begin{array}{l}\text { Introduction of alphabet, numbers, games } \\
\text { matching alphabetrs and numbers }\end{array}$ \\
Genre & $:$ Education of application \\
Platform & $:$ Mobile Android (Construct 2) \\
Audience & $:$ Early Childhood \\
Interactive & $:$ The use of navigation pointers that allow users to \\
& go to desired pages, audio and 2D animation. \\
\hline
\end{tabular}

\section{Design}

To illustrate the design of each scene, the storyboard design for this stage is made an illustration of the visual design scene form, audio, duration, description, and narration for the sound will be made in the storyboard design. In this study the specifications will be made based on the following steps:

\section{Storyboard}

The first step in designing an educational game is to create a storyboard in the form of a set of sketches of images arranged in sequence and adjusted to the script so that the story ideas can be conveyed easily. Here's an example of a storyboard from an English learning media: 


\section{Main course:}

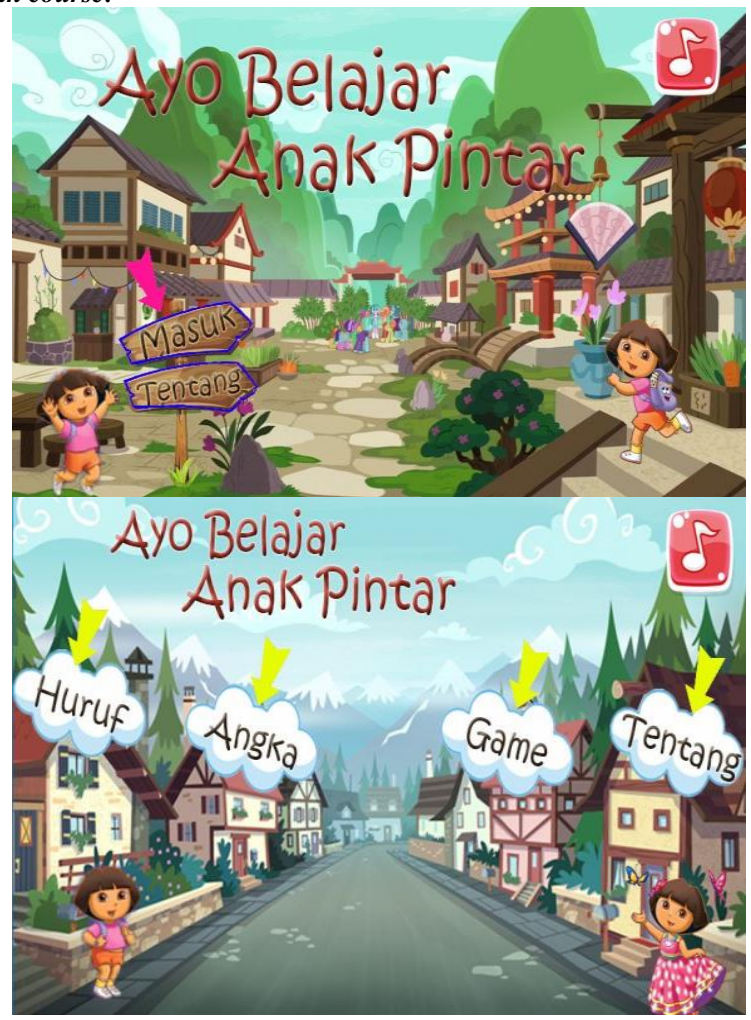

Study menu: There is a choice of learning letters and numbers

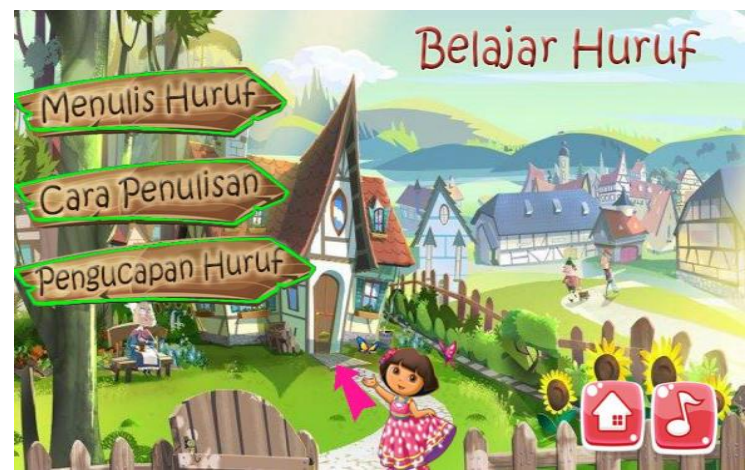

Menu learn to write alphabets: In this menu, users can learn to make letters according to the color choices available

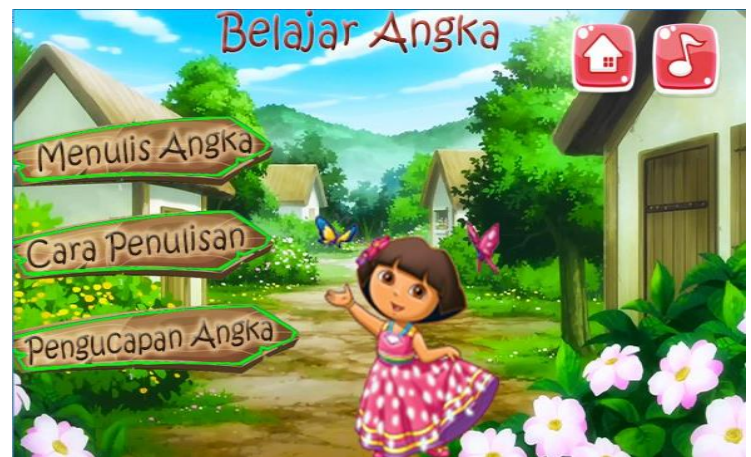

Menu to learn to write numbers: In this menu, users can learn to make numbers according to the color choices available

Figure 4. Description. Application Concept.

\section{Stucture Navigation}

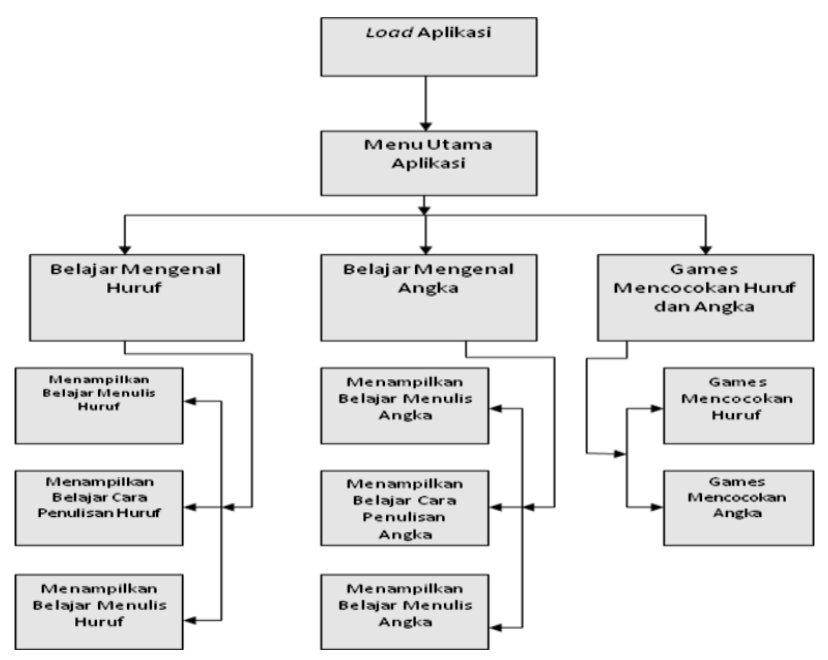

Figure 5. Stucture Navigation.

\section{RESULTS AND DISCUSSION}

\section{Results}

The testing phase of developing English Learning Media uses the ISO 9126 testing standard, testing two of the six characteristics possessed by ISO 9126 namely Usability and Functionality. Usability is to test the ease of use of applications, while Functionality is to test the functions contained in an English learning application.

Table 2. Results of Functionality Characteristic Calculation.

\begin{tabular}{lll}
\hline No. Questions & Success & Fail \\
\hline 1 & 1 & 0 \\
2 & 1 & 0 \\
3 & 1 & 0 \\
4 & 1 & 0 \\
5 & 1 & 0 \\
6 & 1 & 0 \\
7 & 1 & 0 \\
8 & 1 & 0 \\
9 & 1 & 0 \\
10 & 1 & 0 \\
11 & 1 & 0 \\
12 & 1 & 0 \\
13 & 1 & 0 \\
14 & 1 & 0 \\
15 & 1 & 0 \\
16 & 1 & 0 \\
Jumlah & 16 & 0 \\
\hline
\end{tabular}

Based on the test results in Table 2, the percentage of functionality characteristic test can be calculated as follows

$$
\begin{gathered}
\text { Persentase Functionality }=\frac{\text { result score }}{\text { high score }} \times 100 \% \\
\text { Succes }=\frac{16}{16} \times 100 \%=100 \% \\
\text { Fail }=\frac{0}{0} \times 100 \%=0 \%
\end{gathered}
$$


Table 3. Result If Calculation Data For Usability Tes.

\begin{tabular}{|c|c|c|c|c|}
\hline 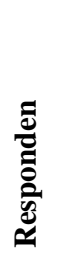 & 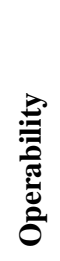 & 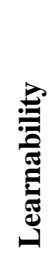 & 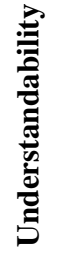 & 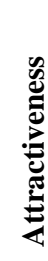 \\
\hline 1 & 20 & 20 & 10 & 72 \\
\hline 2 & 14 & 15 & 8 & 63 \\
\hline 3 & 18 & 19 & 10 & 77 \\
\hline 4 & 17 & 17 & 8 & 62 \\
\hline 5 & 20 & 18 & 10 & 75 \\
\hline 6 & 16 & 18 & 9 & 66 \\
\hline 7 & 17 & 17 & 8 & 76 \\
\hline 8 & 20 & 20 & 10 & 72 \\
\hline 9 & 20 & 19 & 10 & 75 \\
\hline 10 & 19 & 20 & 10 & 73 \\
\hline 11 & 17 & 19 & 10 & 75 \\
\hline 12 & 17 & 18 & 10 & 73 \\
\hline 13 & 20 & 19 & 10 & 80 \\
\hline 14 & 16 & 16 & 9 & 74 \\
\hline 15 & 17 & 18 & 8 & 72 \\
\hline 16 & 18 & 18 & 10 & 75 \\
\hline 17 & 18 & 19 & 9 & 75 \\
\hline 18 & 20 & 20 & 10 & 76 \\
\hline 19 & 18 & 17 & 10 & 67 \\
\hline 20 & 16 & 16 & 9 & 65 \\
\hline
\end{tabular}

Table 4. Calculation of usability test results data.

\begin{tabular}{|c|c|c|c|c|}
\hline 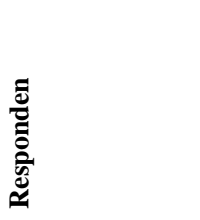 & 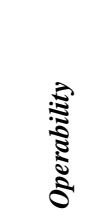 & 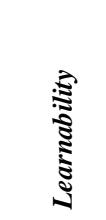 & 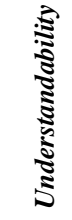 & 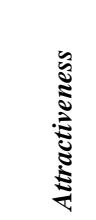 \\
\hline Score Total & 358 & 363 & 188 & 1443 \\
\hline Maksimum & 400 & 400 & 200 & 1600 \\
\hline Presentage & $89,50 \%$ & $90,75 \%$ & $94 \%$ & $90,20 \%$ \\
\hline All Percentage & \multicolumn{4}{|c|}{$91,11 \%$} \\
\hline
\end{tabular}

Table 5. Characteristics on tests that can be used

\begin{tabular}{llll}
\hline No & Characteristic & Presentage & Feasibility Level \\
\hline 1 & Operability & $89,90 \%$ & Very feasible \\
2 & Learnability & $90,75 \%$ & Very feasible \\
3 & Understandability & $94 \%$ & Very feasible \\
4 & Attractiveness & $90,20 \%$ & Very feasible \\
\hline
\end{tabular}

The results of data processing in the usability test stated that the application device has an operability value of $89.90 \%$, learnability $90.75 \%$, understandability $94 \%$, and attractiveness $90.20 \%$. For the overall percentage of the usability characteristics of the custom clothing education game, the score was $91.11 \%$. From the results of the calculation of usability percentage that has been done, it can be concluded that this English learning application is declared very feasible to use.

English learning applications are tested in the software quality test phase based on ISO 9126 (functionality and usability). The results of testing an English learning application for android mobile-based early childhood can be seen in table 6 .

Table 6. The Results of Testing An English Learning Application.

\begin{tabular}{ll}
\hline Characteristic & Result \\
\hline Functionality & $100 \%$ \\
Usability & $91,11 \%$ \\
\hline
\end{tabular}

\section{CONCLUSIONS}

This research and development has succeeded in designing and developing English language learning media for introducing numbers 1-20 and introducing A$\mathrm{Z}$ for early childhood using software construct 2 with Multimedia Development Life Cycle system development methods, by testing the feasibility of the media using ISO 9126 which includes functionality and usability. The results of the media feasibility test results get the results that all components of the game can run according to its function, while the usability test gets a score of $91.11 \%$, which means that English learning media that have been developed for young children are suitable for use as learning media. Making learning media by utilizing technology is one of the revolutions in the field of education, especially in the era of the industrial revolution 4.0. Development and manufacturing of media by utilizing technology will certainly be even better if educators can develop independently, meaning that educators must be able to master software that can be used as a tool for making media, or by holding training and assistance in making learning media by utilizing technology with the expectation of mastery about software will be better which has an impact on the independence of educators in making instructional media in the era of the industrial revolution 4.0

\section{REFERENCES}

Grossard .C, O. et al. 2017. Computers \& Education Serious Games to Teach Social Interactions and Emotions to Individuals with Autism Spectrum Disorders (ASD)," Comput. Educ: 195-211

Miftakh. F., 2015, Pengembangan Media Audio Visual Dalam Meningkatkan Kemampuan Menyimak Mahasiswa, Jurnal Ilmiah Solusi: 17-24.

Sutopo, A. H., 2003. Multimedia Interaktif Dengan Flash, Graga Ilmu. Jakarta.

Very, H.S, et al. 2019. Rancang Bangun Aplikasi Game Matematika Untuk Penyandang Tunagrahita Berbasis Mobile, 
Journal of Computer Science and Information Systems: 116126.

Very, H.S, et al. 2018. Media Pembelajaran Interaktif Menggunakan Macromedia Flash Pada Materi Geometri; Prosiding Seminar Nasional Matematika Dan Pendidikan Matematika 2018. Unsika, Karawang, 29 september 2018.
Very, H.S, et al. 2017. Pengembangan Media Pembelajaran Matematika Berbantuan Multimedia Interaktif Dengan Software Adobe Flash CS4. Prosiding Seminar Nasional Matematika Dan Pendidikan Matematika 2017, UNY, 28 september 2017. 
THIS PAGE INTENTIONALLY LEFT BLANK 